Arch. hist. jap. Vol. 18, n. 2 (November 1959).

P. $169-189$.

Anat. Labor. of Prof. H. SETO, Tohoku University, Sendai.

\title{
On the Sensory Nerve Supply of Dental Pulp, Peridental Membrane, Periosteum, Gum and SERRE's Pearl in the Lower Jaw of Five-Day-Old Kitten.
}

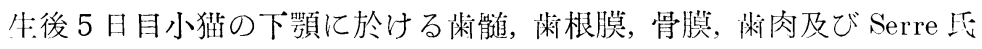 \\ 真珠の知覚神経分布に就て。
}

Mizuo MOGI 茂木瑞夫.

(Received June 8, 1959.)

Many reports have appeared since olden days on histological studies on the sensory innervation of the peridental membrane and the dental pulp and this frecuency of reported studies itself eloquently tells of the high importance of the subject. At this laboratory too, YAMAZAKI reported on the subject with the adult human materials and TOKUMITSU with those of dog, while SHIRAISHI made an embryological research on the nerves in these parts of 3rd-10th month human fetus, TOKUMITSU reported on the special sensory terminations in the periosteum of the lower alveoli of dog and SHIRAISHI obtained very interesting results in his study on the sensory nerve supply of the SERRE's pearl and the gum of human adults and fetus. TOKUMITSU et al. made another research on the canine gum.

The present author was given the opportunity of studying the sensory innervation of the lower jaw of a 5-day-old kitten. I know of no study on the subject with young animals of a few days after birth reported in the past. The materials of my study were first fixed in $10 \%$ neutral formol solution for a long time, cut into $40 \mu$ frontal serial sections, stained by SETO's impregnation method. The large series of beautifully stained preparations thus obtained were thoroughly examined and the findings were studied in comparison with the findings observed in the corresponding parts in man and dog in the studies cited above from the viewpoint of comparative histology. The results were as reported in the following.

\section{Individual Findings.}

The teeth growing on the lower jaw of my five-days kitten were as yet gone not very far on their course of development, and as could be readily anticipated, the sensory nerve distribution, especially, the formation of sensory terminations, was not in full completion. The picture of these undeveloped terminations made me ponder on the long way of differentiation they have to travel until the teeth attain full maturity.

My specimens being so small and the entire elevation of the lower jaw including the teeth, the gum and all the other organs and tissues being visible in one frontal section, it was very convenient for me that the courses of the n. alveolaris inferior, its plexus formation as well as the distribution of the nerve fibres to every organ in 
it could be very easily observed.

Prefacing my description of the sensory nerve supply of the part, I will speak a word on the histological structure of the parts of the kitten's lower jaw. At this stage, the milk teeth are not yet cut and lie hidden in the gum, but the germs of the permanent teeth are already in formation beside the buds of milk teeth (Fig. 1).

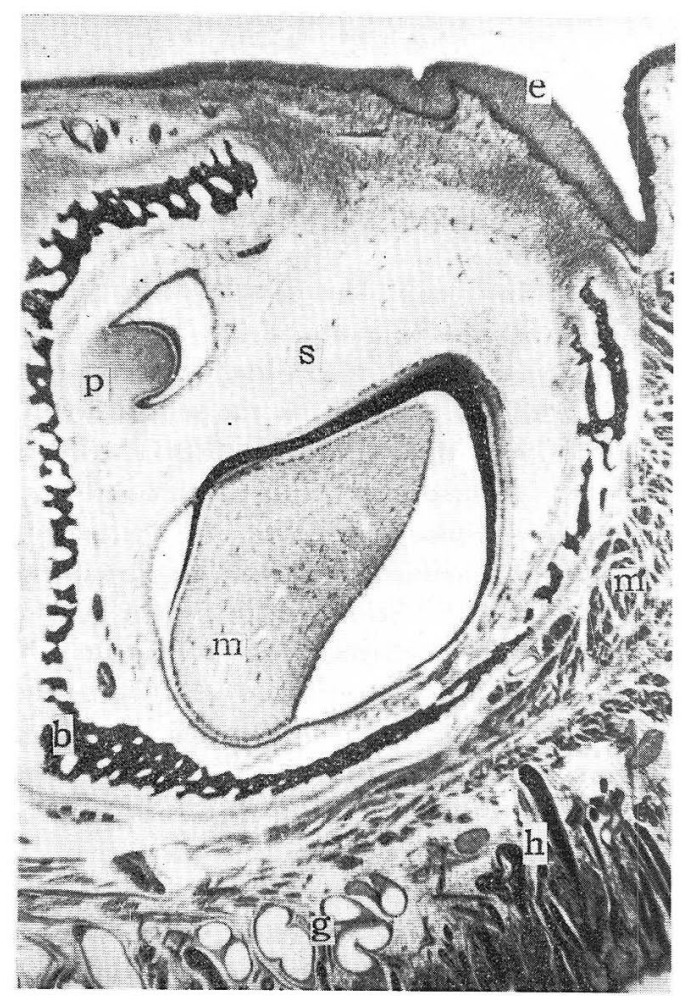

Fig. 1. A low magnification of a cross section of the lower jaw of a newborn cat. $e$ epithelium of the gum, $m$ milk tooth, $p$ permanent tooth, $s$ dental sac, $b$ jaw bone, $m$ ' muscle tissue, $h$ and $g$ hairs and sweat glands

in the skin. SETO's impregnation. Photo $\times 24$.

The epithelium on the free margin of the gum rising above the tops of these teeth is very thick, consisting of 17-20-rowed stratitied flat epithelium, but more to the peripheral on both sides of the gum it gratually loses in thickness, and finally passes over into the 7-8-rowed flat epithelium generally lining the oral cavity (Fig. 1). The epithelium of the gum is composed of much larger and clearer epithelial cells than those forming the epithelium of the oral cavity.

Into this epithelium lining the gum of the kitten, papillae are formed out of the propria beneath, as shown in Fig. 2, but they are as yet in the course of development and are poorer than those in 10th month human fetus (FUNABASHI), being only undersized things of varied height. The lamina propria is composed of some- 


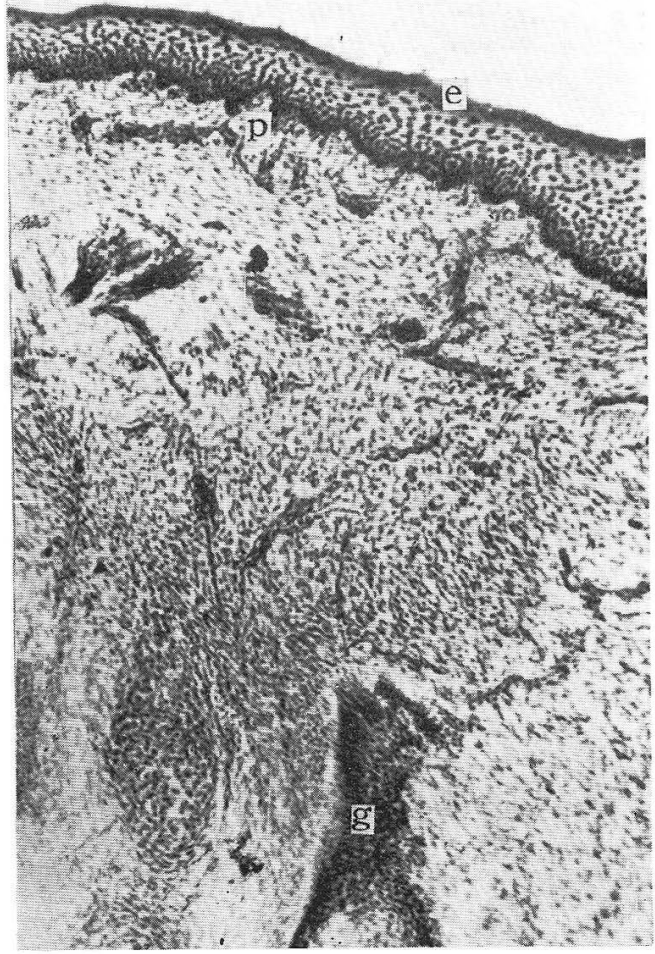

Fig. 2. Proprial plexus in the mucous membrane of the lower gum of a newborn cat. e non-cornified stratified flat epithelium, p papillae from the propria, g dental germ. Same staining. Photo $\times 60$.

what loosely arranged fibrocytes and forms a rather clear layer.

The points to be noted in the lower jaw of such a newborn kitten were the existence of milk teeth and permanent teeth in respectively different stages of development, and of the dental laminae and their rudimentary formations, the so-called SERRE's pearls. The jaw bone is also still in incomplete development, and it is of interest that its periosteum is formed of dense-packed large oval or round young connective tissue cells (Fig. 7).

The nerve bundles of the $n$. alveolaris inferior entering the canalis mandibularis through the foramen mandibulae form the plexus dentalis inferior beneath the bases of the milk teeth in this canal (Fig. 3), and the plexus sends out rami dentales inferiores and rami gingivales inferiores toward the milk teeth and the gum, These alveolar nerve bundles are formed of medullated thick sensory fibres in the main and a small number of non-medullated vegetative fibres.

The peridental membrane filling the spaces between the alveoli in the mandibular bone and the teeth being not yet, fully developed in my kitten specimen corresponding to the incomplete development of the teeth, is not of the specific stout connective tissue of spindle-form fibrocytes as in adult animals, but of loose connec- 


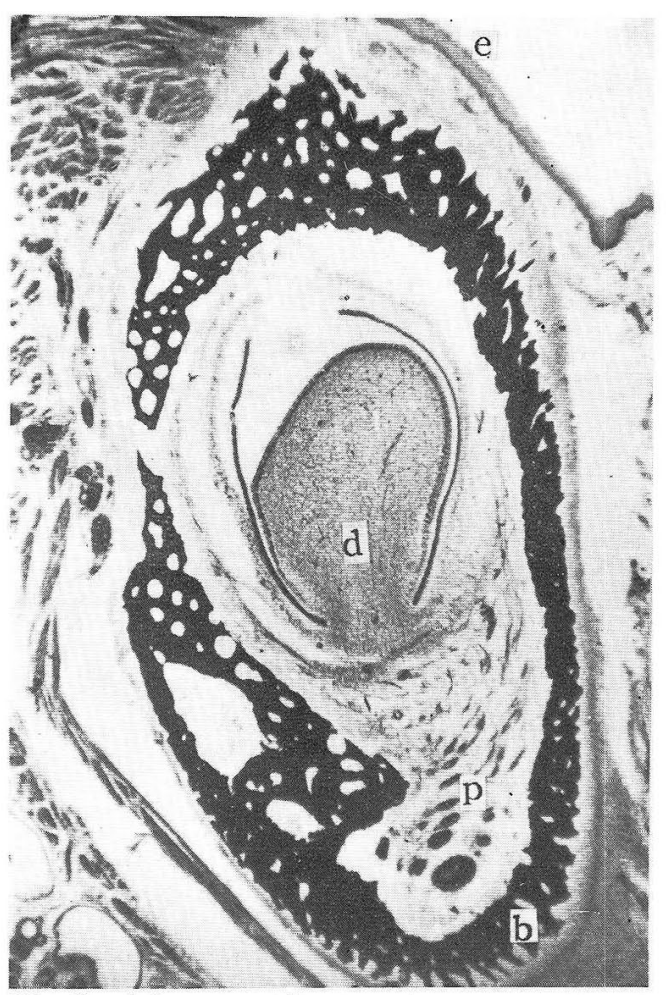

Fig. 3. A low magnification of a cross section of the lower jaw of a newborn cat. $b$ jaw bone, $e$ epithelium of the gum, $p$ plexus dentalis formed beneath a young milk tooth having neither enamel nor dentine in formation, $d$ dental pulp having not yet supplied nerve fibres. Same staining. Photo $\times 24$.

tive tissue of the dental sacs described below (Figs. 1 and 3). In this infantile peridental membrane of young loose connective tissue, however, dental plexus is already in very powerful formation, particularly in the bases of the teeth. As clearly seen in Fig. 3, or more distinctly under higher magnification in Fig. 4, nerve bundles of varied sizes from the alveolar nerve spread out in various directions in the loose connective tissue surrounding the bases of the milk tecth and form very complex dental plexus.

The rami dentales inferiores from the plexus run into the dental pulp of the milk teeth formed of densely arranged young fibrocytes, in company with small blood vessels. The quantity of nerve fibres changes in proportion to the development of the individual tooth, but at this infantile stage the milk teeth being still so immature that no foramina apicis and canalis apicis dentis are formed as in adult cat, the few nerve branches run right into the convexly bulging dental pulp through its basis (Fig. 4).

The peridental membrane between the alveolus and a tooth is of as yet very 


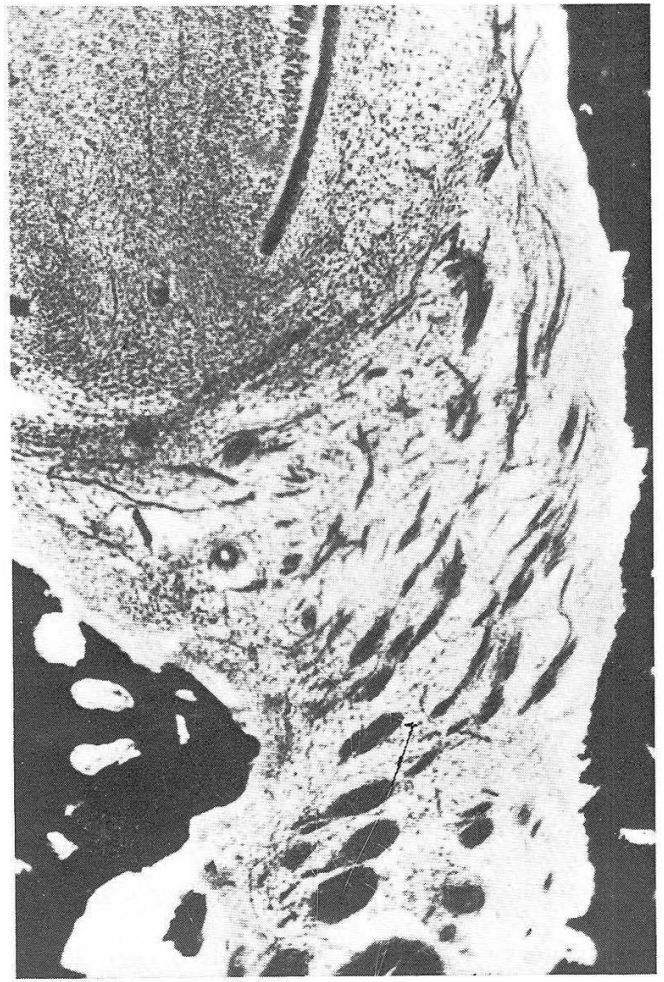

Fig. 4. Higher magnification of the plexus dentalis in Fig. 3. Photo $\times 60$.

immature connective tissue, as described above, which contains plexus sending out a rather large number of small nerve bundles of rami gingivales inferiores that run peripheralwards while branching out, finally to form the proprial plexus in the propria mucosae of the gum (Fig. 2).

Such a picture of nerve distribution is made very distinct by the very perceptible development of the nerve fibres concerned. The vegetative fibres already form clearcut STÖHR's terminal reticula here and there. The terminations of the sensory fibres, however, are still in very infantile state of development far poorer than in adult man and dog, as described below.

My kitten specimens have revealed that the age at which the dental nerve branches run into the dental pulp of the milk teeth is much later than I had anticipated. As shown in Fig. 3, the dental pulp, in which the enamel is not yet developed out of the inner cell layer of the enamel organ and the odontoblast layer has not yet produced the dentine, is still devoid of any nerve fibres. First, when the enamel and the dentine comes into clear formation, the nerve fibres begin deliberately to enter the dental pulp. For example, in the dental pulp of a milk tooth with the enamel and the dentine in somewhat perceptible formation, as shown in Fig. 1, nerve fibres are found running in, though indeed in a very small number. In the dental 
pulp exemplified in Fig. 5, the enamel and the dentine are considerably better developed and the surrounding enamel pulp has become rudimentary, so a rather large number of nerve fibres are found installed. Even in such a pulp, however, the

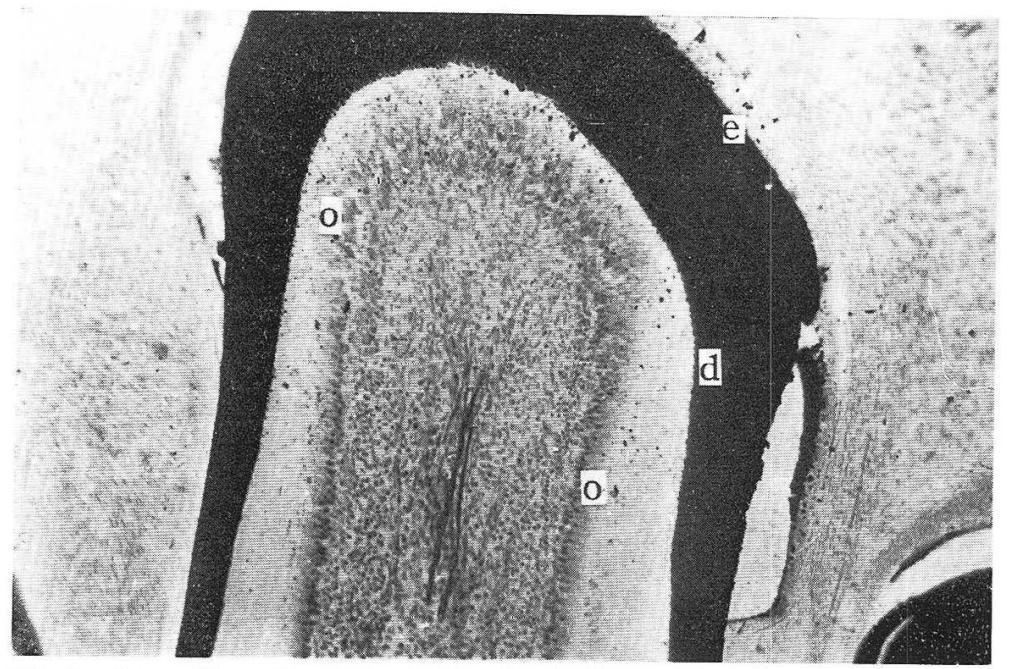

Fig. 5. Nerve fibres found in the dental pulp of a milk tooth having enamel $(e)$ and dentine $(d)$ in formation. Cross section of the lower jaw of a ncwborn cat. $O$ odontoblast layer. Same staining. Photo $\times 100$ ).

number of the incoming nerve fibres cannot be called very large at all and no RASCHKOW's plexus could be found beneath the odontoblast layer. It is probable that the nerve distribution to the pulps does not come into completion before the teeth are fully matured.

As the dental nerve fibres begin to enter gradually the dental pulps first in a very late stage of dental development, as described above, the terminations of the sensory fibres in my kitten pulps were very small in number and very simple in form.

Many authors including YAMAZAKI and TOKUMITSU of this laboratory have reported on the nerve supply to the teeth in adult man and animals. According to their reports, sensory fibres form terminations of various types not only in the dental pulp but in the odontoblast layer as well. In my kitten specimen, however, no sensory fibre was found running so far as into the odontoblast layer, that is, no intra-odontoblast nerve fibres could be detected in my preparations; only some fibres were found in the connective tissue of the dental pulp at a distance from this layer, ending in unbranched and more rarely in simple branched terminations. Their terminal fibres are merely thin strands showing little change in size and no mentionable winding in their courses (Fig. 6).

At our laboratory, SHIRAISIII has conducted a research on the growth and the sensory nerve supply of the young permanent teeth of human fetus. He says that the growth of the permanent teeth of 6th month human fetus is of the same order as that of the milk teeth in the later 3rd month; their dental germs are of 


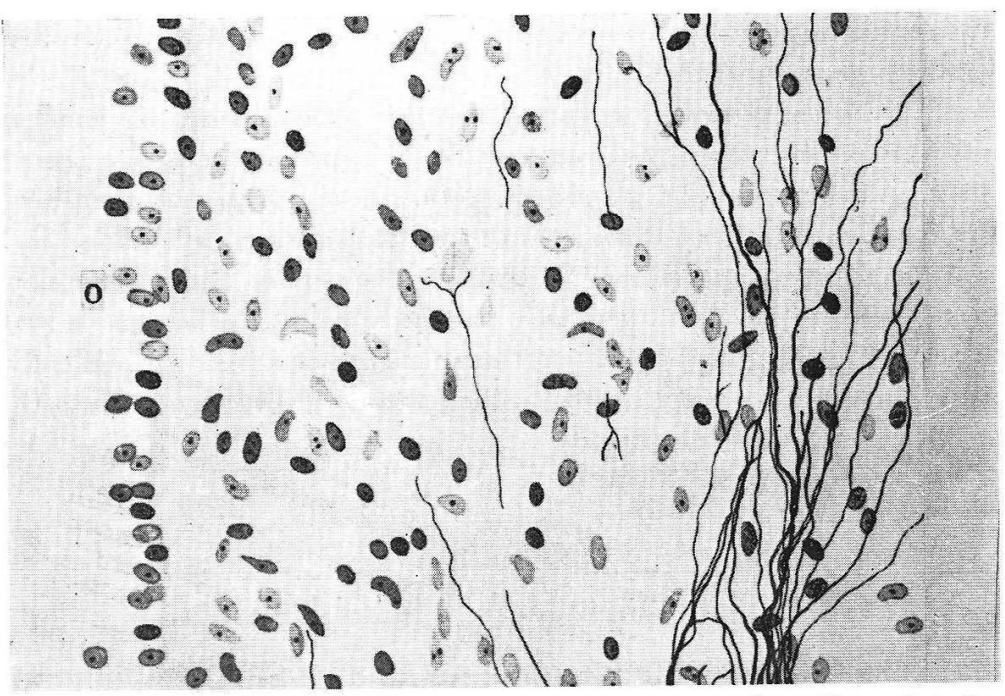

Fig. 6. Nerve distribution in a well developed dental pulp of a milk tooth in the lower jaw of a newborn cat. Some unbranched and bifurcated sensory terminations are seen at a distance from the odontoblast layer (o). Same staining. $\times 320$.

cap-form and dental papillae are formed out of the mesodermal tissue toward their inner surface and connective tissue cells containing spindleform nuclei cover up the entire arrangement. Such germs of permanent teeth of rather low maturity could be found in my kitten too, but here I found also some more differentiated germs with more or less well-developed enamel pulps (Fig. 1). Fig. 7 shows a part of Fig. 1 in higher magnification. Around such better-developed permanent teeth, however, the

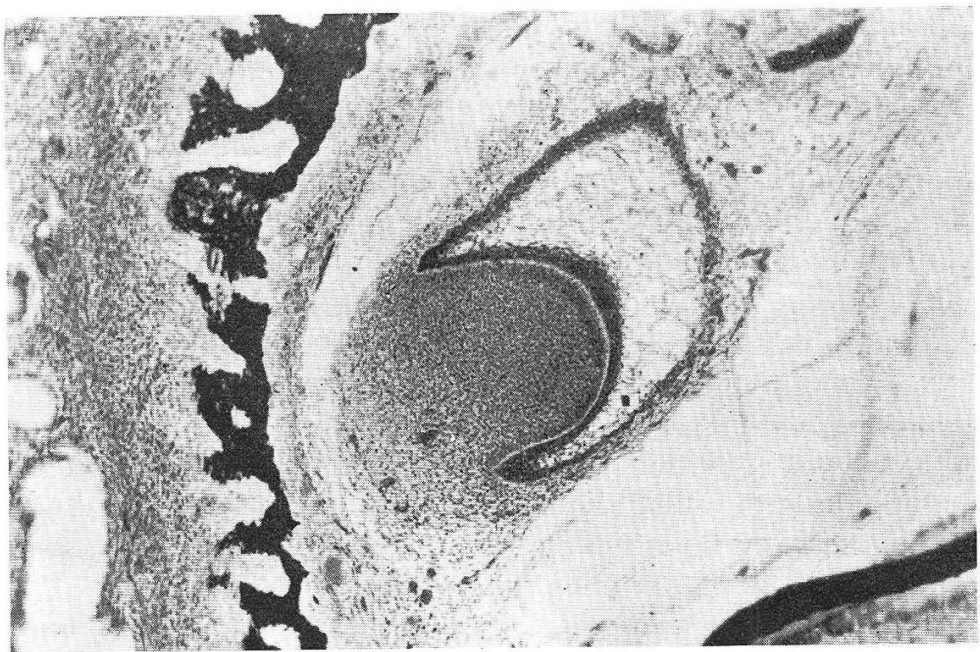

Fig. 7. Higher magnification of the permanent tooth in Fig. 1. Sensory fibres can not be found entering into the vicinity of the outer cell layer of the enamel pulp in this felal stage. Photo $\times 60$. 
stout connective tissue was nearly gone and in its place, a loose connective tissue of the dental sac comes into formation.

In my specimens of kitten, sensory fibres in a somewhat smaller number than in man (SHIRAISH) were found running into the specific connective tissue layer surrounding the germs of the permanent teeth. On rare occasions, the fibres were found to run into the epithelial tissue of the dental germs too. Of course, no nerve fibre was found yet within the dental papillae. The sensory fibres coming into this connective tissue are usually rather thick and end in unbranched or simple branched terminations. Their terminal fibres sometimes undergo change in size and end either sharply or bluntly (Figs. 8 and 9). But in the better-developed permanent tooth with

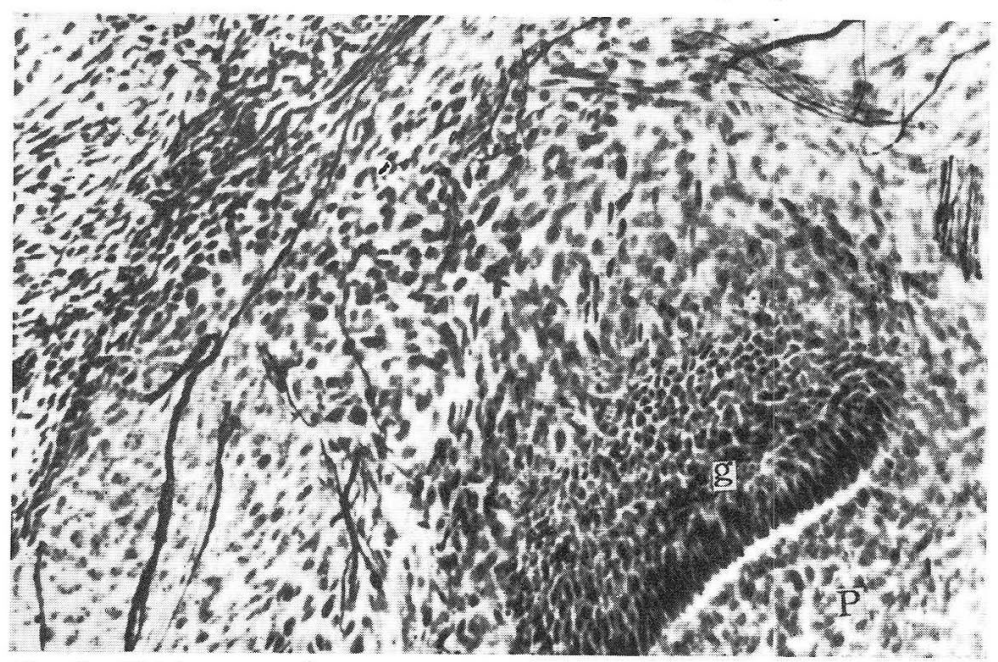

Fig. 8. Thick sensory fibres and their branched terminations found in the connective tissue layer surrounding the dental germ $(g)$ of a permanent tooth in the lower jaw of a newborn cat. Thin fibres are vegetative fibres, $p$ dental papilla. Details in the text. Same staining. Photo $\times 200$.

enamel pulp formed in the dental germ and loose connective tissue of the dental sac surrounding it, no sensory fibre could be found at all in the vicinity of the outer cell layer (Fig. 7).

Now, in the vicinity of the basis of the dental pulp of the permanent tooth germs, nerve plexus was in much poorer development than beneath the milk-tooth germs. The sensory fibres originating in such plexus probably begin to invade the dental pulp here in the stage when enamel bogins to form, as in the case with the milk teeth, and it is a very interesting problem whether the root-fibres of the nerve fibres in the milk teeth falling into degeneration when the teeth are shed are regenerated to supply the fibres innervating the dental pulp of the permanent teeth taking their place or new nerve fibres are produced for the purpose.

The peridental membrane between the milk teeth and the alveolar bone in $\mathrm{my}$ kitten was mainly composed of the loose reticular connective tissue forming the dental sac, only a small part of it being represented by the sout connective tissue composed of very closepacked spindle-form connective tissue cells, as usual in adult 


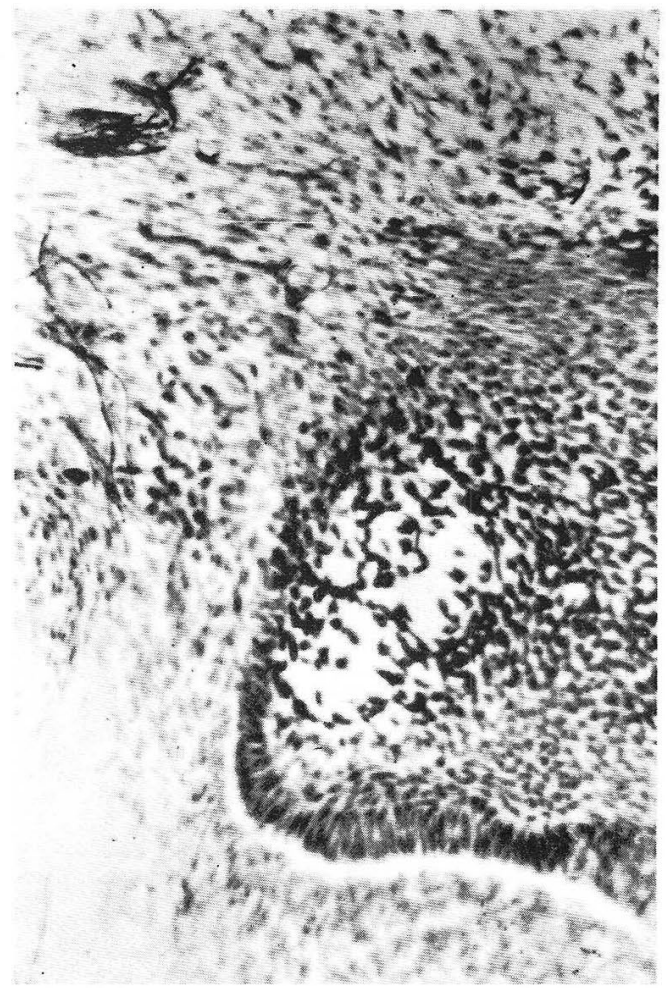

Fig. 9. Ditto.

animals. Nerve fibres from the rami gingivales from the plexus dentalis run through this young peridental membrane and send out some sensory fibres into the membrane in their courses.

Branched terminations of very peculiar formation were found in the peridental membrane of adult man (YAMAZAKI) and adult dog (TOKUMITSU), having thick terminal fibres very frequently changing their size in their very peculiarly winding courses.

A rather large number of sensory terminations originating in thick or finer fibres were found in the peridental membrane around the milk teeth of my newborn cat. But in form these are much simpler than in adult man and dog, being usually of simple branched type. Their terminal fibres, however, are very often, show change in size peculiar to sensory fibres and some peculiarity in their winding as found in adult animals, and such terminations are of a type suggestive enough of the possibility of their developing into the specific endings found in the peridental membrane in adult animals. As shown in Fig. 10, unbranched and very simple branched terminations may be formed by such particularly thick fibres, while in Figs. 11 and 12 , where some branched terminations composed of $2-5$ terminal fibres formed by thick fibres are very distinctly illustrated, we see the terminal fibres undergoing peculiar change in size and running rather uncommon courses, and giving a clear indication 


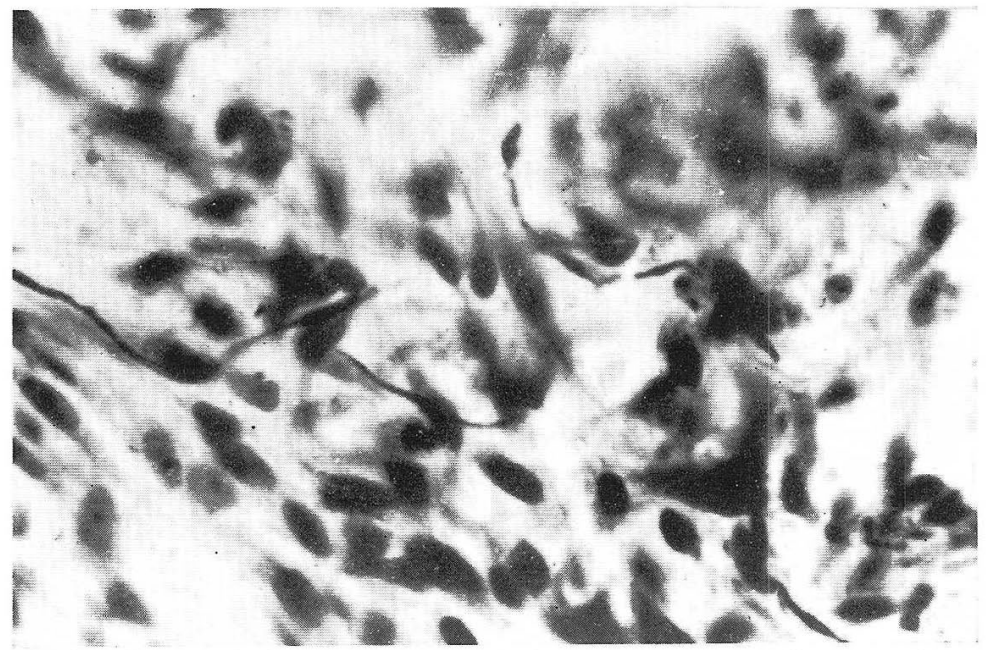

Fig. 10. Unbranched and simple branched sensory terminal fibres showing a conspicuous change in size found in the peridental membrane surrounding a milk tooth in the lower jaw of a newborn cat. Same staining. Photo $\times 800$.

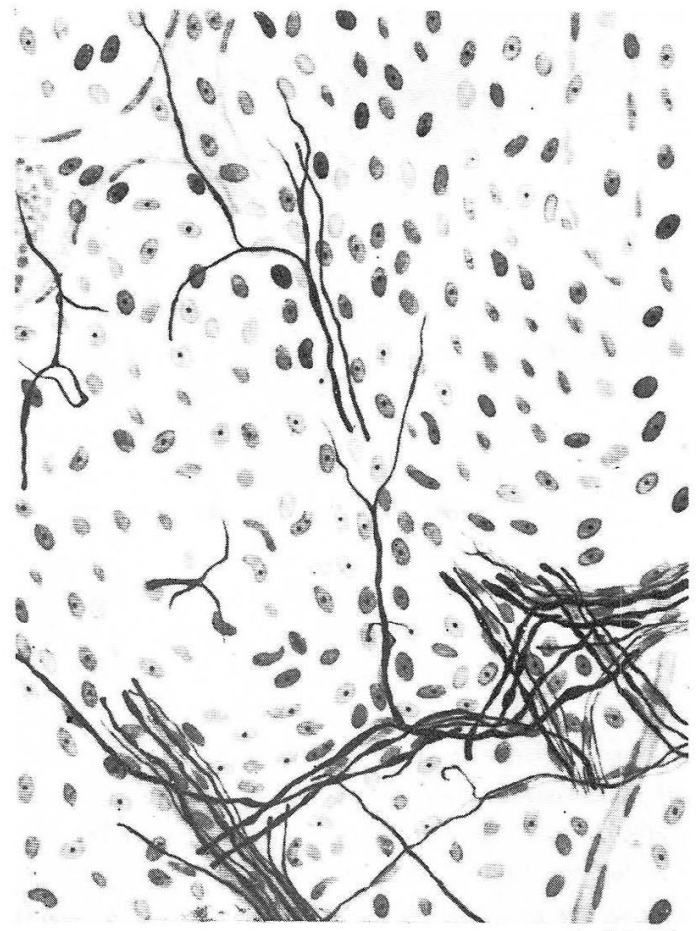

Fig. 11. Some simple branched sensory terminations composed of $3-5$ terminal fibres showing peculiar change in size and winding courses found in the peridental membrane in the lower jaw of a newborn cat. Thick fibres are sensory and thin fibres are vegetative fibres. Details in the text. Same staining. $\times 320$. 


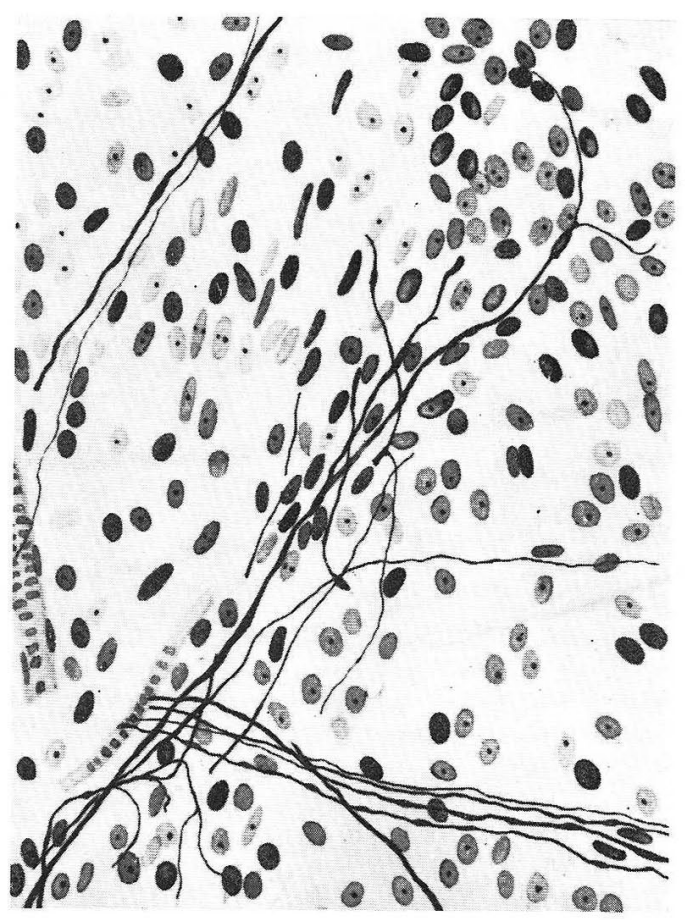

Fig. 12. Ditto. Same staining. $\times 320$.

of their development into so many very peculiar complex branched terminations found in adult animals.

TOKUMITSU has not rarely found in the periosteum of the alveolar margin of the mandible in dog very peculiar branched sensory terminations composed of terminal fibres mainly running looped courses and has made a detailed report on it. I could also find very interesting terminations in the young periosteum of all the areas of the mandible of my infant cat. These terminations were present in a particularly large number in the periosteum of the alveolar margin, as in dog, and ware much more numerous in my newborn cat than in TOKUMITSU's adult dog.

In a newborn cat, the bone tissue of the mandible is as yet in the course of development and accordingly its periosteum is also in incomplete differentiation. As shown in Fig. 13, the periosteum consists of an outcr fibrous connective tissue layer composed of spindle-form cells and fine fibres and an inner osteogenetic layer composed of round cells, and a layer of osteoblasts differentiated more widely from these round cells is found lining the inside of this osteogenetic cell layer and covering the bone tissue containing bone cells transformed from these osteoblasts. Thus, ossification is still actively going on in the different parts of the mandible of infantile cat.

Thick sensory fibres are found running into this young periosteum, often accompanying fine vegetative fibres, especially notably in the periosteum of the alveolar margin (Fig. 13). Upon reaching their terminal area, these sensory fibres part from the accompanying vegetative fibres and after a repeated ramification, end in simple 


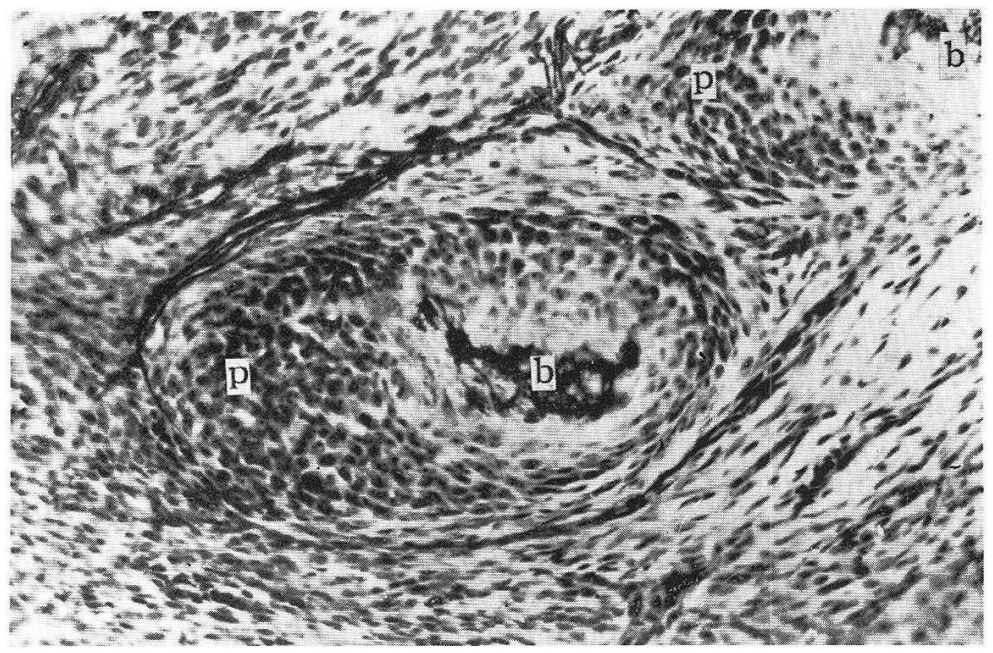

Fig. 13. Small nerve bundles chiefly composed of thick sensory fibres reaching the young periosteum $(p)$ of an alveolar margin of the lower jaw of a newborn cat. $b$ bone tissue. Details in the text. Same staining. Photo $\times 200$.

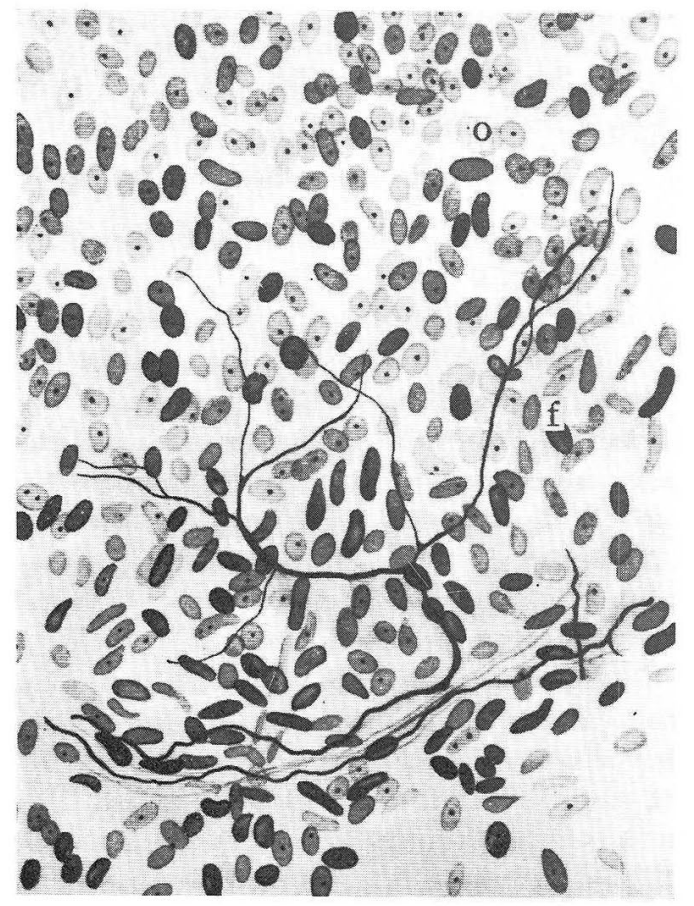

Fig. 14. A complex branched sensory termination distributed in the periosteum of an alveolar margin of the lower jaw of a newborn cat. f fibrous connective tissue layer and o osteogenetic layer of the periosteum. Details in the text. Same staining. $\times 320$, 
or complex branched terminations.

The terminal fibres of these sensory terminations of adult dog are comparatively thick fibres showing little change in size and are characterized by their looped courses, and end in the outer fibrous layer of the periosteum. In my kitten, the case was somewhat different; the sensory fibres were in some cases rather thin, though in most cases were thick enough, their terminal fibers not rarely changing size and comparatively few of them ran looped courses. Besides, in some cases, a thin fibre suddenly changed into a thick fibre. These terminal fibres run into the fibrous layer of the periosteum, further into the osteogenetic layer (Fig. 14) and even as far as into the osteoblast layer before terminating. It is very interesting that such very peculiar terminations could be found in a newborn cat.

In Fig. 14 is shown a rather complex branched termination found in the fibrous layer of the periosteum of the alveolar margin, originating in a thick sensory fibre and having 8 terminal branches. These terminal fibres show not much change in size and looped courses and end mostly in sharp points. In Fig. 15 are shown a few branched terminations formed along small vessels in the fibrous layer of the periosteum near the alveolar margin in the foremost part of the mandible. All of these termina-

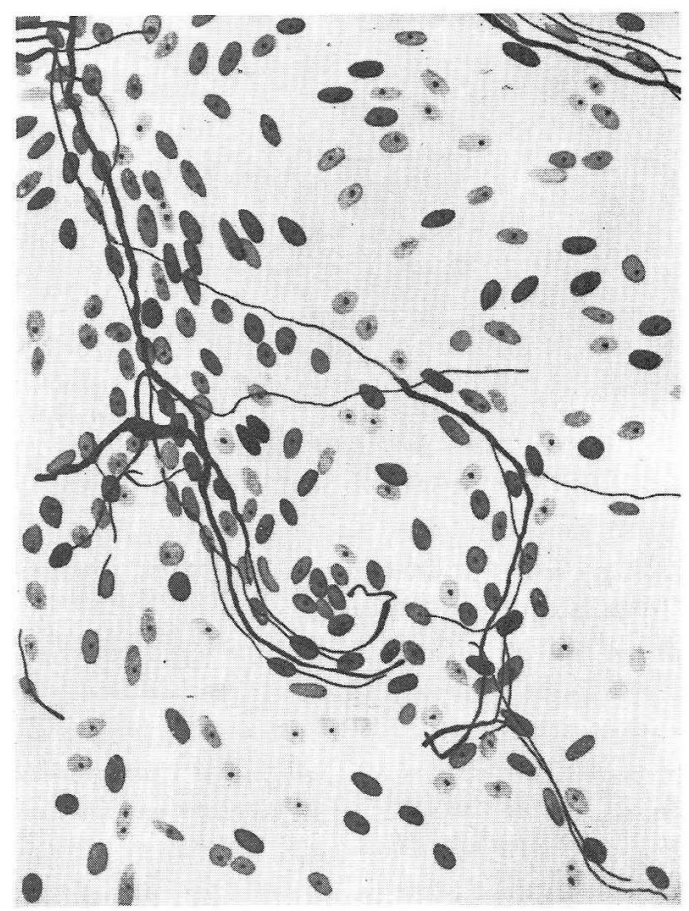

Fig. 15. Some branched sensory terminations found in the fibrous layer of the periosteum near an alveolar margin of the lower jaw of a newborn cat. Terminal fibres originated in thick stem fibres show perceptible change in size and end sharply. Details in the text. Same staining. $\times 320$. 
tions are formed by thick fibres, except one that is originated in a thin fibre. The terminal fibres of the former not rarely show perceptible change in size, sometimes run looped courses and usually end sharply. In the latter, some of the thin terminal fibres abruptly expand into thick fibres. In Fig. 16 are illustrated again a few

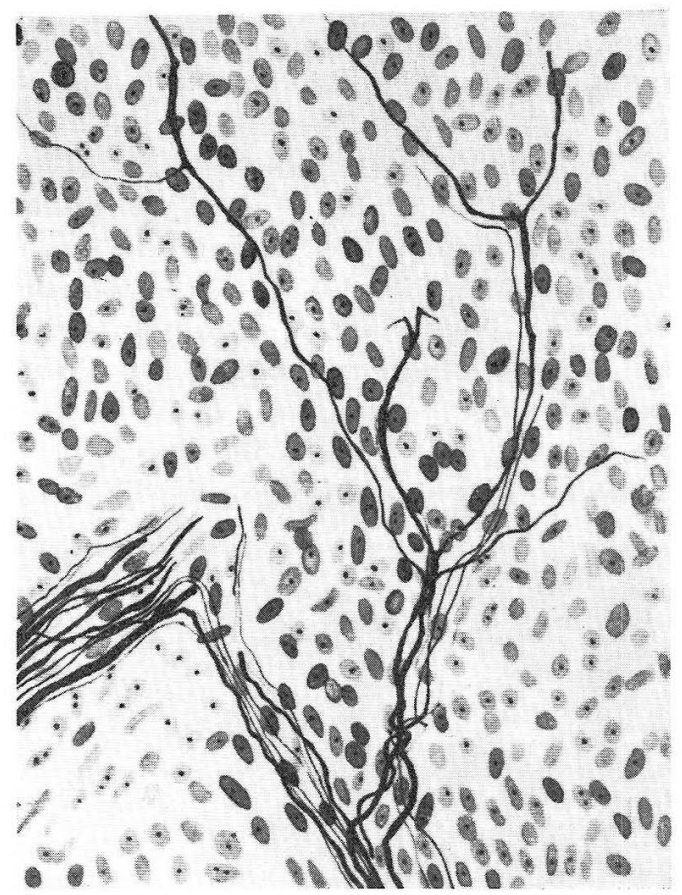

Fig. 16. A few simple branched sensory terminations originated in thick stem fibres found in the same place as in Fig. 15. Their terminal fibres show particularly perceptible change in size. Same staining. $\times 320$.

simple branched terminations originated in thick sensory fibres found in the same region as the preceding. The terminal fibres here show particularly perceptible change in size but little looping in their courses.

SHIRAISHI found sensory terminations in the large SERRE's pearls representing relics of the dental laminae in 8-10th month human fetus, and he reported on the not at all presence of small-sized SERRE's pearls in human adults, too and to our further surprise on the existence of intraepithelial fibres in them.

In my newborn cat, I found SERRE's pearls somewhat smaller than those found in the lower jaw of human fetus and showing as yet no cornification in their inner parts. These formations, as shown in Fig. 17, are composed of small-and large-sized epithelial cells in the peripheral and the central parts, respectively.

Now, sensory fibres are found running into the SERRE's pearls in the case of newborn cat as well. As is clear in that illustrated in Fig. 17 and under higher magnification in Fig. 18, a small number of sensory fibres run into the central part of such a pearl from the surrounding tissue. These fibres are usually thin, but not 
Fig. 17. Intraepithelial fibres found in a SERRE's pearl $(s)$ in the lower jaw of a newborn cat. $p$ germ of a permanent tooth. Details in the text.

Same staining. Photo $\times 200$.
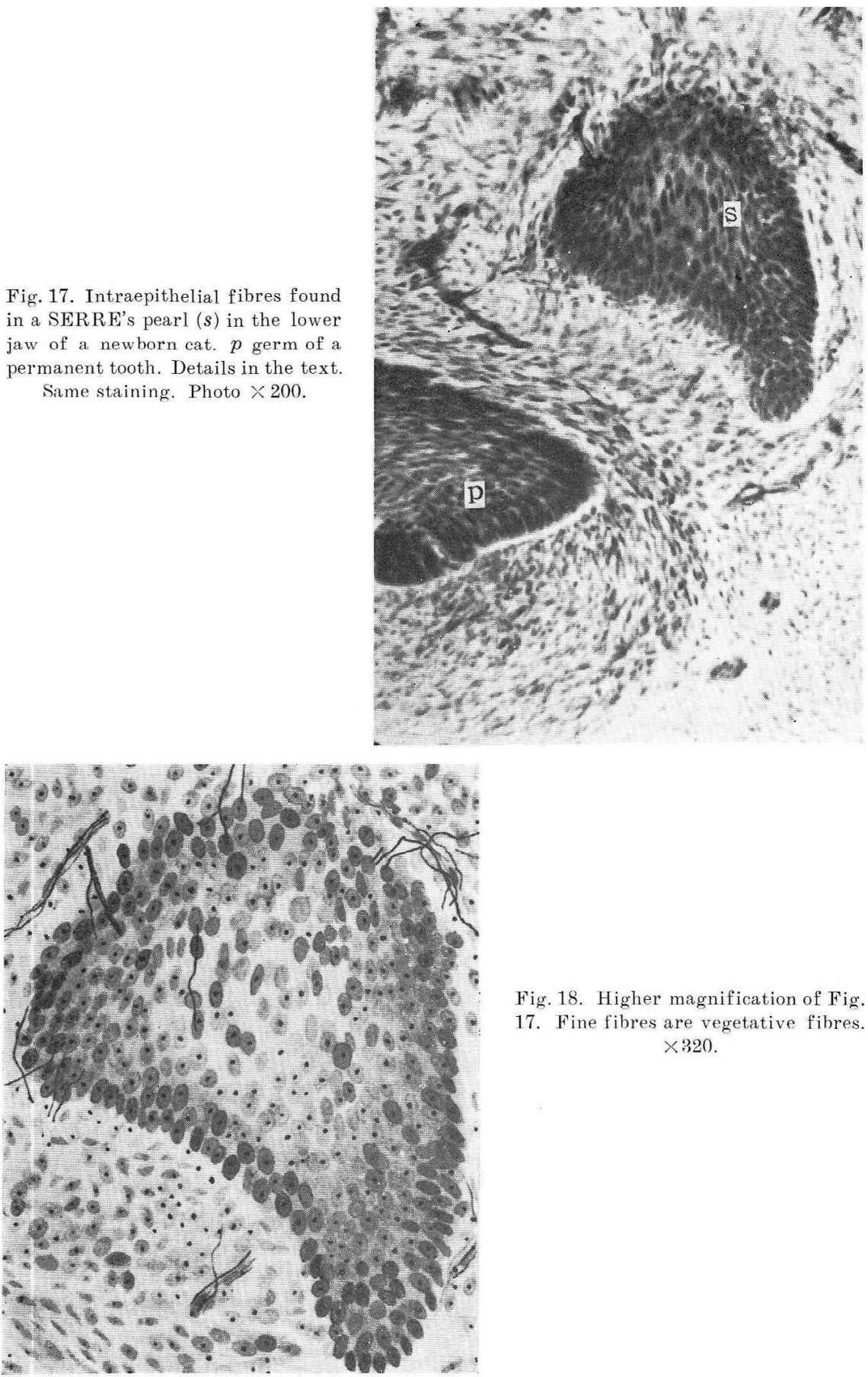

Fig. 18. Higher magnification of Fig. 17. Fine fibres are vegetative fibres. $\times 320$. 
rarely thick fibres also come forth among them; their terminations are somewhat simpler than in man, usually consisting in unbranched or bifurcated intraepithelial terminations. In general, these intraepithelial fibres show little change in size or winding in their courses, but sometimes run marked looped courses (Fig. 19).

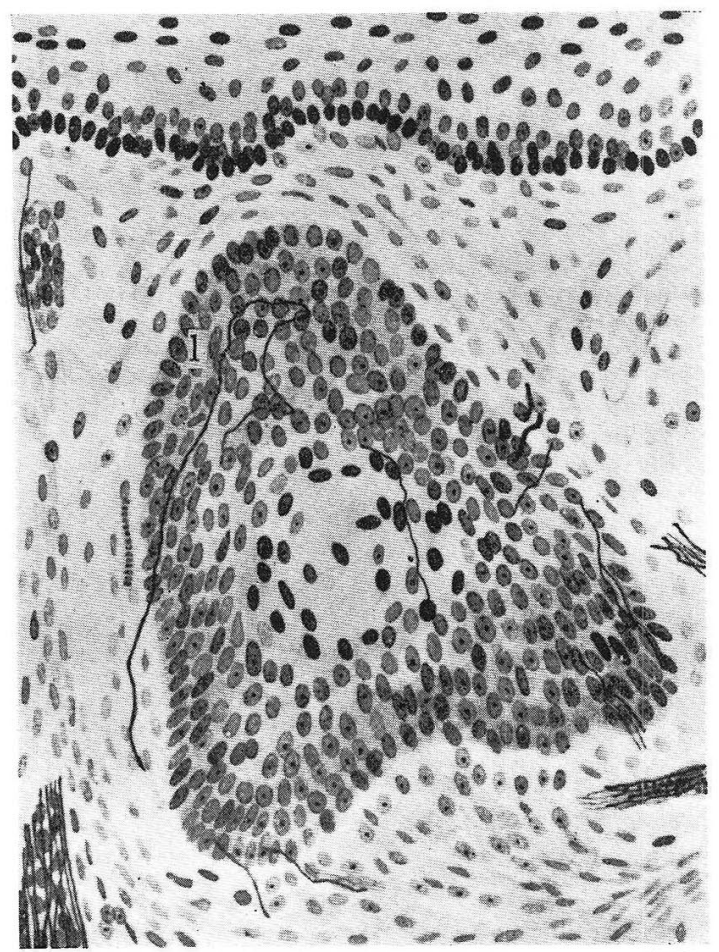

Fig. 19. Intraepithelial sensory fibres found in a SERRE's pearl in the lower jaw of a newborn cat. $l$ somewhat thick intraepithelial fibre running a marked looping course. Same staining. $\times 200$.

Thus in the SERRE's pearls of my kitten, as well as of man, intraepithelial sensory fibres were in perceptible formation. This fact seems to indicate that these formations are sensory organs of some kind and not such endocrine organs as some old authors have presumed.

The considerable richness of the gum in sensory fibres has been already pointed out by many authors and my kitten specimen was not at all an exception. Many sensory fibres, as already stated, arise from the proprial plexus of the gum and besides forming their terminations in the propria, also end in intraepithelial fibres.

The deep layer of the propria of the interdental gum forms an extension of the already rather well-developed peridental membrane, and contains a considerable number of branched terminations originating in thick fibres and having terminal fibres showing frequent change in size and windings in their courses, as does the peridental membrane described above (Fig. 20). The loose connective tissue forming 


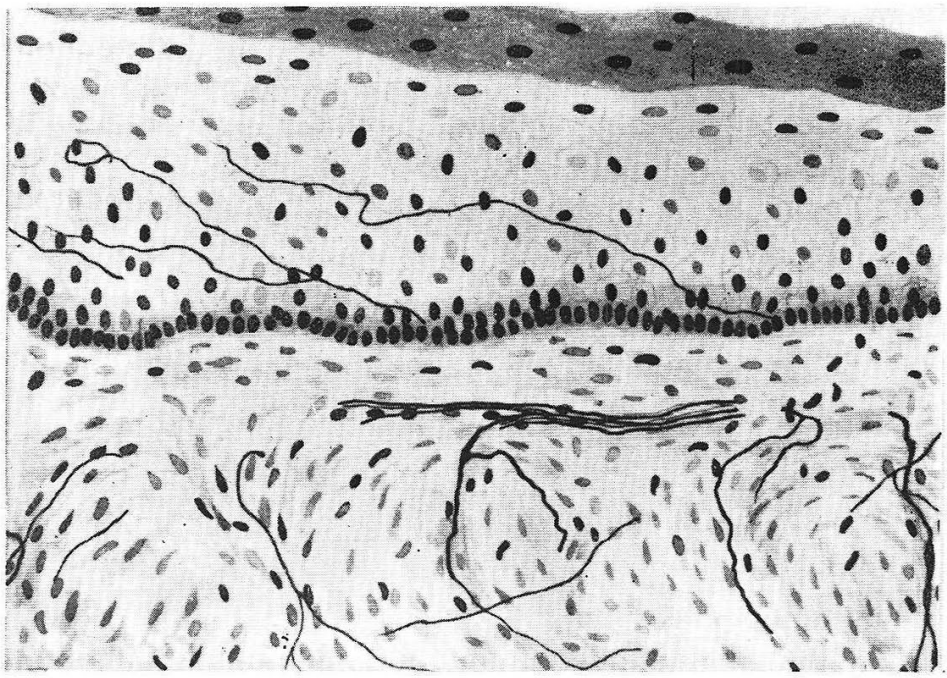

Fig. 20. Unbranched and simple branched sensory terminations found in the deep layer of the propria and in the epithelium of the interdental gum of a newborn cat. Details in the text. Same staining. $\times 320$.

the surface layer of the propria contains many somewhat simpler terminations, but in some cases, the terminations are of rather more complex branched type, than in the deep layer above (Fig. 21). No such complex glomerular terminations as found in the gum of human adults could ever be found here.

As illustrated in Figs. 20 and 22, intraepithelial fibres here are even better

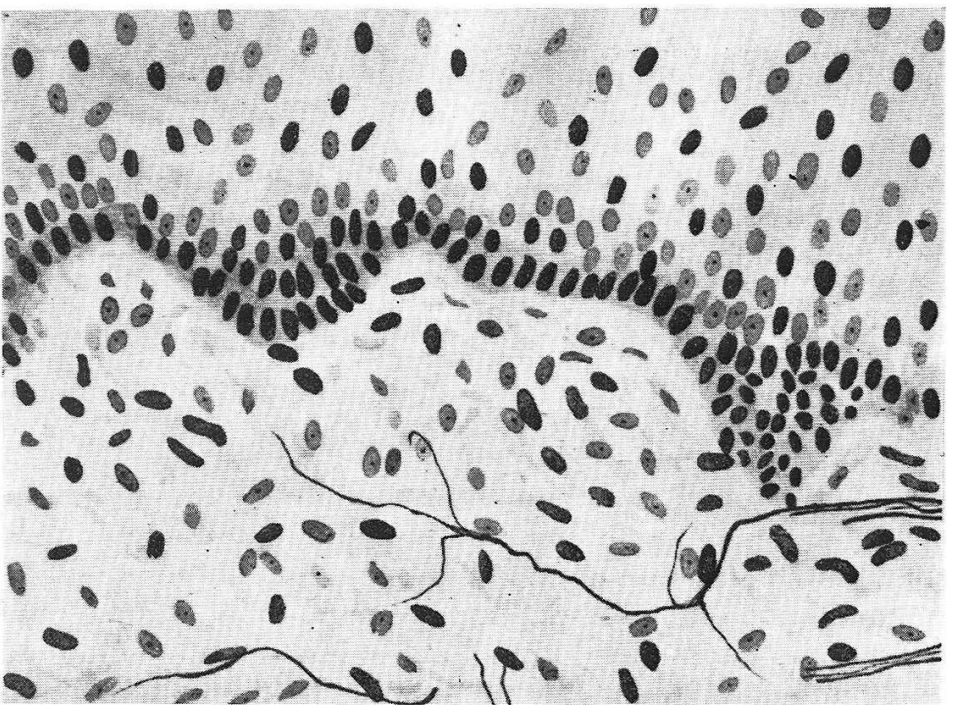

Fig. 21. A branched sensory termination composed of 5 terminal fibres showing change in size found in the superficial layer of the proria of the lower gum of a newborn cat. Same staining. $\times 320$. 
developed than in adult dog; usually, they are thin fibres undergoing little change in size and forming simple branched terminations, the terminal fibres running very long inter- and intracellular courses as do the intraepithelial fibres in general, and end usually sharply but sometimes bluntly and on rarer occasions in a loop (Fig. 20). Some of the fibres run rather markedly winding courses (Fig. 22).

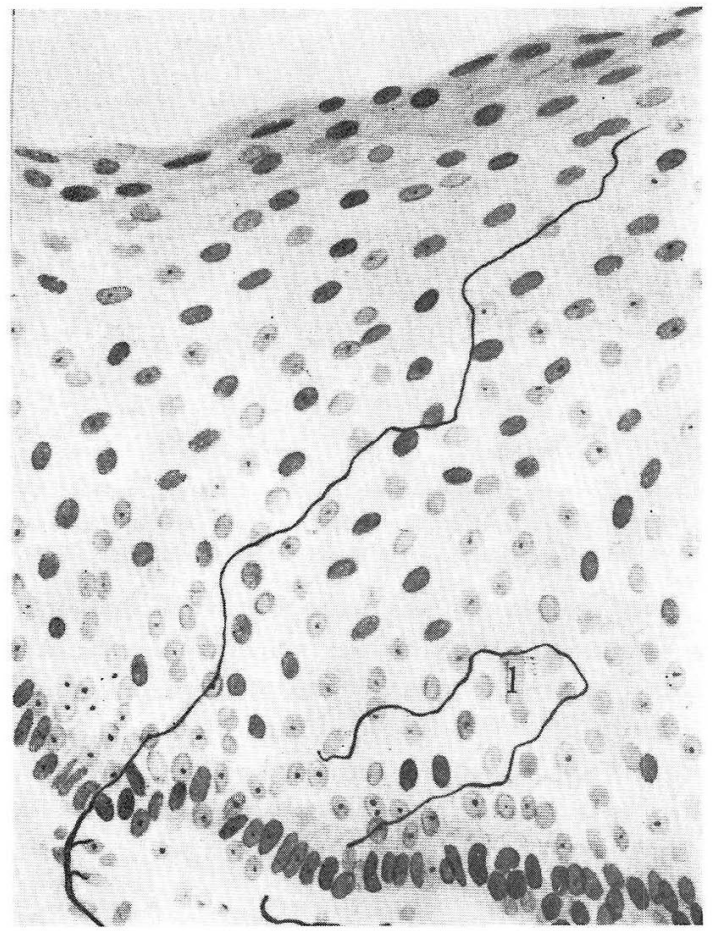

Fig. 22. Intracpithclial fibres running intra- and intercellularly and undergoing little change in size found in the epithelium of the lower gum of a newborn cat. $l$ intraepithelial fibre running a looping course. Same staining. $\times 320$.

\section{Summary.}

In a 5-day-old kitten, the plexus dentalis originating in the $n$. alveolaris inferior of the lower jaw was found already very well developed, comprising numerous thick sensory fibres and far less numerous thin vegetative fibres.

The rami dentales emerging from this plexus run into the dental pulp of the milk teeth, the number of the nerve fibres increasing abreast with the growth of the teeth. Now, the time these nerve branches enter the dental pulp was found considerably later than was anticipated, for the innervation begins only in the stage where enamel is produced from the enamel organ and dentine from the odontoblasts. Thus, the number of nerve fibres to the dental pulp of the still growing and yet uncut milk tooth is very limited, only a few sensory fibres ending in mere unbran- 
ched and simple branched terminations at some distance from the odontoblast layer, no RASCHKOW's plexus being as yet found in formation. No such fibres innervating the odontoblast layer or complex branched terminations in the dental pulp as found in adult animals were found in the mandible of my kitten. The terminal fibres of the existent sensory terminations show little noteworthy change in size or winding in their courses.

In my kitten, as found in a 6 th month human fetus (SHIRAISHI), besides the milk teeth, immature permanent teeth consisting merely of a cap-shaped dental germ and a dental papilla and somewhat better differentiated permanent teeth were contained in the lower gum. Thick sensory fibres were found entering the rather powerful connective tissue layer covering these buds of permanent teeth and sometimes even the dental germ. These fibres end in unbranched and simple branched terminations with terminal fibres of ten showing change in size in their courses before ending in sharp points.

The peridental membrane between the milk teeth and the alveolar wall is formed in the main of the loose reticular connective tissue forming the dental sac and only in very limited areas by the stout connective tissue as in adult animals. Many nerve fibres from the rami gingivales arising from the plexus dentalis were seen running through this immature peridental membrane toward the propria of the gum while sending out a considerable number of sensory fibres into the membrane in their courses. Their terminations were much simpler than in man and adult dog, simple branched ones forming the majority. Their terminal fibres, however, sometimes show change in size and unusual winding in their courses suggestive of their probable development into very peculiar complex branched terminations as found in adult animals.

Some specific sensory terminations were found in the entire area of the young periosteum of the mandible of my kitten, especially, in the alveolar margin. The bone tissue was as yet in the course of growth and the periosteal tissue was still immature, being composed of an outer fibrous connective tissue layer, an osteogenetic layer lining it and an osteoblast layer on the inside. Thick sensory fibres run into this young periosteum accompanying some fine vegetative fibres, and after a repeated ramification end in simple and complex branched terminations. Their terminal fibres often show conspicuous change in size and run into the fibrous layer and fur. ther into the osteogenetic layer, even into the osteoblast layer before terminating.

In the lower jaw of my newborn cat, I found a small number of SERRE's pearls somewhat smaller in size than those in human fetus. A small number of sensory fibres are found running into these pearls, as in the case with man (SHIRAISHI), forming unbranched or bifurcated terminations therein with terminal fibres showing not much change in size and winding in their courses. The SERRE's organs are presumably so many sensory organs.

The proprial plexus originating in the rami gingivales and formed in the propria of the gum sends out sensory fibres which form their terminations in the propria or further up in the epithelium. The deep layer of the interdental gum representing an extension of the already well-developed stout connective tissue of the peridental membrane contains a rather large number of branched terminations originating in 
thick fibres and of a type specific to the peridental membrane. The loose connective tissue forming the surface layer of the propria contains terminations simpler than the preceding. The intraepithelial fibres are of unbranched or simple branched type and are usually very well developed, running out very long intracellular courses.

\section{内 容 自 抄.}

生後 5 日目猫の下顎内の下歯神経叢は甚だ良好な华達を示し, 多数の太心知覚 線維と少量の細い植物線維とから成る。乙の神経叢からの㐘枝は幼若乳㐘の桠乳 頭内に進むが，その神経線維の量は乳翻の発達状態に比例する，とてろでこの㐘 乳頭内に神経線維の入り込む時期は可なりおそく, 即ちエナメル器からエナメル が生じ，ゾウゲ芽細胞層からゾウゲ質の出来る頃に初めてその進入を見る。 そこ で尚発達途上にあり，而も未だ窲肉の表面に見われないての幼若乳㐘の㐘乳頭に 進む神経線維の量は極めて少なく，Raschcow 氏神経叢も未だ形成されず，僅かの 知覚線維はゾウゲ芽細胞層から可なり離れて非分岐性及び単純性分岐性終末に終 るに過ぎない.

乳料の傍らには人胎生巾期に見られると略ぼ同一形状の永久萪の原基が見られ るが, その㐘芽周囲の強い結合織内には太い知覚線維が進入, 稀には菊第の上皮 細胞愿の巾に迄達する。等線維は非分岐性及び単純性分岐性終末に終るが，乙 の終末枝は屢々太さの変化を示し，その先端は概ね尖鋭状に終る.

乳㐘と㐘槽壁間の㐘根膜は蔝囊の粗鬆結合織で構成されるが，このけを㐘神経 叢からの㐘肉枝の多数の神経線維が料肉に向う。その途上茷根膜にも多数の神経 線維が送られる。乙の萪根膜に形成される知覚絈末は尚幼若性の分岐性終末で表 われるが，その終末枝は特有な太さの変化と走行とを示し，成長せる動物に見ら れる特殊形態の分岐性終末への発達過程を思わしめる.

下顎骨の骨膜に特殊形状の知覚終末が可なり多量に発見される。特に莯槽縁に 於て然りである。乙の化骨途上にある骨の骨膜も甚だ幼若性のものであるが，之 に対し知覚線維が進入し, 再度の分岐の後, 単純な, 時には叮なり複雑な分岐性 終末に終る。終末枝は特有な太さの变化を示し，最外層の線維層のみならず， 勫の造骨層, 更に稀ならず造骨細胞層の川に迄も入って終る。

柬肉内には少量の Serre 丘真珠が発見されるが，この川に小量の知覚線維の進 入を見，その上皮内終末は非分岐㤬夃び単純性分岐性終末で表われる。

㐘肉には著明な圆有膜神経攱が形成され, 之より起る知覚線維は上皮下及び上 皮内にその終末を作る。菻間歯肉は強靶な結合織から成り，この小には歯根膜に 見られる様な太い線維に由来する可なり複雑な特殊分岐性終末が形成されるが, 一般歯肉の固有脱では単純性分岐性終末が見られ，上皮内では非分岐性及び単純 性分岐性終末が見られるが，其発達は甚だ良好である。 


\section{References.}

Calderon, L. : Contribution à la connaissance de l'innervation des dents. Nerfs de la pulpe dentaire et leurs terminaisons. Trav. Lab. Rech. Biol. Madrid. 26 (1930). - Dependorf : Beiträge zur Kenntnis der Innervierung der menschlichen Zahnpulpa und des Dentins. Dtsch. Mschr. Zahnhk. 31 (1913). - Nervenverteilung in der Zahnwurzelhaut des Menschen. Dtsch. Mschr. Zahnhk. 31 (1913). - Funabashi, K.: On innervation of hard palate in human embryo. (Jap) Tohoku Igaku Zassi. 35 (1947). - Huber, G. C.: The innervation of the tooth-pulp. Dental Cosmos. 40 (1898). - Jurjewa, E.: Die Nervenendigungen im Zahnfleisch des Menschen und der Säugetiere. Fol. neurobiol. 7 (1913). - Kadanoff. D.: Die Innervation des Zahnfleisches beim Menschen. Z. Zellforsch. 6 (1927-28). - Kaji, I.: Die Verteilungen der Nervenfasern am Gaumen und Gingivalschleimhaut beim Menschen. (Jap.) Rinsho Shika. 9 (1938). - Lewinsky a. Stewart: The innervation of the dentine. J. Anat. 70 (1935-36). - Morgenstern, M.: Über die Innervation des Zahnbeins. Arch. Anat. u. Physilo., Anat. Abt. 1896. - Beitrag zur Kenntnis der Nerven in den Zähnen. Dtsch. Monatsschr. Zahnhk. 14 (1896). - Mummery, J. H.: On the distribution of the dental pulp. Proc. roy. Soc. London. 85 (1902). - The nerve supply of the dentine. Proc. roy. Soc. Med. 5 (1912). - The innervation of dentin. Dental Cosmos. 58 (1916). - Riegele, L.: Beitrag zur Kenntnis der Innervation des menschlichen Dentins. Z. Zellforsch. 20 (1933). - Römer, O : Über Sensibilität des Zahnbeins. Dtsch. Mschr. Zahnhk. 17 (1899). — Rygge, J.: Über die Innervation der Pulpa. Internat. Mschr. Anat. u. Hist. 19 (1902). - Shiraish. ., K.: Histological, especially embryological study on innervation of human gum and tooth. Tohoku Igaku Zassi. 45 (1951). - Stewart, D.: The problem of the innervation of the dentine. J. Anat. 61 (1927). - Tiegs, O. W.: Nerve endings in human teeth. J. Anat. 66 (1931). Tokumitsu, Y.: On the innervation, especially, the sensory innervation of the peridental membrane, the dental pulp and the periosteum of the lower alveolus in dog. Arch. hist. jap. 10 (1956). - Tokumitsu, Aiba, Takahashi a. Toyota: On the sensory innervation of the gum of dog. Arch. hist. jap. 10 (1956). - Weatherford, H. L.: The innervation of the teeth in the albino rat with some observations on the finer structure of the dental pulp. Anat. Rec. 74 (1934). - Yamazaki, J.: On innervation of human dental pulp. (Jap.) Tohoku Igaku Zassi. 38 (1948). - - On innervation of human dental radical membrane. (Jap.) Tohoku Igaku Zassi. 38 (1948). 